\title{
Online Learners and Their Self-Disclosure Preferences
}

\author{
Anne Doring, Ashley Hodge, and Misook Heo \\ Duquesne University, Pittsburgh, PA, USA
}

\section{doringa@duq.edu; hodgea@duq.edu; heom@duq.edu}

\begin{abstract}
To understand and identify information-sharing preferences among online students, a US survey collected data from university students. Specifically, this study analyzes students' information disclosure preferences and to what extent demographics influence a student's willingness to disclose personal information. This study also examines whether or not students feel more comfortable sharing information with specific user groups, such as teachers, teachers' assistants (TAs), classmates, or friends. While using the communication privacy management theory as a theoretical framework, it was found that graduate students were significantly more likely than undergraduate students to share information with many different groups. Specifically, graduate students disclosed more information to teachers, classmates, group-members, and the TA group when compared to undergraduate students. In addition, graduate students were more likely than undergraduate students to share specific categories of information, including work-related information and contact information. These results provide important insights into how graduate students and undergraduate students interact within online learning environments.
\end{abstract}

Keywords: information sharing preferences, communication privacy management theory, social constructivism, online learning environments, online privacy settings.

\section{Introduction}

Online education is continually evolving to provide a flexible environment that accommodates a variety of students and learning styles. In light of Darkenwald and Merriam's (1982) definition of an adult learner as a self-guided and internally-motivated learner, adults, in particular, can benefit from online learning as it provides an adaptable format for participants to learn as selfdetermined students (Cercone, 2008). Specifically, constructivism, which highlights learnercentered environments and stresses that knowledge is socially constructed, has been used to evaluate the ways instructors and students interact in online learning environments (Huang, 2002). It is not a new concept that interaction is a factor in education; however, its role has been

Material published as part of this publication, either on-line or in print, is copyrighted by the Informing Science Institute. Permission to make digital or paper copy of part or all of these works for personal or classroom use is granted without fee provided that the copies are not made or distributed for profit or commercial advantage AND that copies 1) bear this notice in full and 2) give the full citation on the first page. It is permissible to abstract these works so long as credit is given. To copy in all other cases or to republish or to post on a server or to redistribute to lists requires specific permission and payment of a fee. Contact Publisher@InformingScience.org to request redistribution permission. repositioned from face-to-face $(\mathrm{F} 2 \mathrm{~F})$ to online settings (Anderson, 2004).

While online learning frees students from the physical constraints of colocation, it may potentially hinder students' ability to socially interact with their peers. As social interaction is being recognized as a core component for higher student motivation and satisfaction (Cobb, 2009; Sung \& Mayer, 2012), 
it is important that researchers understand students' desire, or lack thereof, to disclose information as a way to promote social interaction connection in online environments.

When designed correctly, online learning environments can address individual learners' preferences and assist learners in attaining their desired level of learning (Ally, 2004). Some researchers suggest that online learning environments may provide a social classroom where students feel more connected to one another when compared to F2F environments (Walther, 1996). More recent studies show these classrooms as environments that foster relationships (Walther \& Parks, 2002). Online learning environments that promote discourse among students and instructors can provide learners with a more meaningful learning experience (Kiriakidis, 2008). Additionally, online learning environments can foster collaboration and community building as well as allow for learners to connect with and utilize a greater range of shared resources (Ma \& Yuen, 2010).

Social networking systems (SNSs) facilitate the social connections of the participating individuals and support online communities. In SNSs, individuals determine the amount of information being disclosed (Boyd \& Ellison, 2008). Used in online learning environments, SNSs can thus promote interaction and socialization among students, support informal learning, build the learning community, and improve motivation (Dabbagh \& Kitsantas, 2012; Leskovec, Huttenlocher, \& Kleinberg, 2010; Roblyer, McDaniels, Webb, Herman, \& Witty, 2010).

The primary goal of this study is to identify privacy and information-sharing preferences among university students. Specifically, this study intends to understand students' information disclosure preferences, and to what extent demographics influence a students' willingness to disclose personal information. The study also looks at whether or not students feel more comfortable sharing information with specific user groups, such as teachers, teaching assistants, classmates, or friends. This information will give insight into the role of social interaction in online environments and the design and implementation of online education.

\section{Literature Review}

Online social software, such as SNSs, is a commonly used communication medium among students of higher education. In fact, 90.3 percent of 30,616 undergraduate students enrolled in 115 US institutions reported that they use social networking sites, and this number is steadily increasing (Smith, Salaway, \& Caruso, 2009). Unfortunately, however, these students access social networking sites for recreational use, but not necessarily academic use (Alexander, 2008; Forkosh-Baruch \& Hershkovitz, 2011; Madge, Meek, Weelens, \& Hooley, 2009). While the use of social communication in courses is limited, SNSs can be used in online environments to promote learning and build social connections among learners and instructors (Dabbagh \& Kitsantas, 2012). From a social constructivist perspective, online learners require a certain amount of social learning, which is influenced by the learners' ability to foster relationships and socially communicate with others in the online setting (Huang, 2002). SNSs can influence student engagement and social connectivity in online courses (Dabbagh \& Kitsantas, 2012) and promote interaction and socialization among learners (Leskovec et al., 2010; Livingstone \& Brake, 2010; Roblyer et al., 2010). Although SNSs can foster social interaction in online learning, standard implementation does not always result in successful social interaction (Kreijns, Kirschner, \& Jochems, 2003). Understanding the social dimension of interaction can enhance the chances of effectively implementing SNSs (Kreijns et al., 2003).

When individuals are physically separated and capable of presenting themselves in carefully defined ways, they can potentially construct a more controlled representation of themselves and avoid the social preconceptions that are sometimes found in F2F environments (Simonson, Smaldino, Albright, \& Zvacek, 2000). Privacy concerns may influence a student's willingness to share the information necessary for self-definition, and in turn, hinder social connections made 
within online learning environments (Chen \& Bryer, 2012). Researchers, however, disagree on the factors that can influence such privacy concerns. Some suggest that demographics, such as gender and age, may play a role in a student's willingness to connect with their online peers (Junco, 2011). Some comment on conformity as a factor; individuals have a tendency to reveal compliance among those who are involved (e.g., majority talk about a certain topic or share a certain kind of information) (Dron, 2007). Another supposed factor is students' learning styles (e.g., autonomous learners choose to influence the social structure and more dependent learners choose to be more influenced by the social structure) (Dron, 2007). Regardless of the influencing factors, users of SNSs have the ability to control their privacy settings (Stutzman \& KramerDuffield, 2010). Researchers turn to the Communication Privacy Management (CPM) theory to explain how and why users manage their personal information in SNSs (Child \& Petronio, 2011; Metzger, 2007).

Communication Privacy Management (CPM) differentiates between private and public information and outlines a set of rules that are followed when determining which private information to disclose (Petronio, 2002). By defining the borders between private and public information, privacy is carefully balanced with the need to form relationships. Students are more willing to disclose personal information in low-risk environments and less willing to disclose this information in high-risk environments (Metzger, 2007), suggesting that students' perception of risk level determines how much information will be disclosed.

Originally developed to understand how people decide to disclose information, CMP has expanded to include other settings (Metzger, 2007), such as online environments. While examining social network usage in online learning environments, it was found that online students consciously select specific profile information to disclose to particular groups (e.g., the instructor, teaching assistant (TA), classmates, working group members, and existing friends) (Heo, 2011). In line with CPM, the findings show that students carefully weigh their desire to make personal connections with their need to maintain a certain level of privacy. This behavior suggests that not only do students consider privacy when presenting themselves in online environments, but they actively set rules and boundaries to protect specific, personal information.

\section{Research Question Development}

From a social constructivist perspective, the ability of students to make connections and interact with other students is an important aspect of reaching a desired level of social learning when participating in online courses (Huang, 2002). Self-disclosure, one of the factors that positively contributes to social presence (Polhemus, Shih, \& Swan, 2001), has been witnessed to yield an increase in the quantity and depth of interaction within online learning environments (Swan, 2002), and to help establish a common ground among the learning group (Ziegler, Paulus, \& Woodside, 2006). Additionally, recent literature has suggested that participants in online environments carefully reveal specific categories of information in order to self-disclose and connect with others (Chou \& Chen, 2009).

While social communities thrive when participants willingly share personal information (Palen \& Dourish, 2003; Strater \& Lipford, 2008), privacy is also an important aspect of the socialization process, as privacy is necessary for intimacy (Gerstein, 1984; Gross \& Aquisti, 2005). Acknowledging privacy concerns while facilitating the social aspect of the online community is crucial, as perceptions of community are important to online learning (Song, Singleton, Hill, \& Koh, 2004). Within online environments, privacy is often explicitly controlled through profile settings (Strater $\&$ Lipford, 2008). Through examining profile settings within online learning environments, researchers and instructors may better understand how online learners balance their privacy concerns with their need to disclose information. In addition to examining online privacy settings, online teaching practices may also benefit from an improved understanding of how individual 
student demographics influence disclosure and privacy preferences. By creating the proper balance between privacy and public community, and by considering the various demographic information that may influence perceptions of privacy, students may experience enhanced social learning within their online learning communities.

Based on 99,000 student responses collected across 108 institutions, of which approximately 29,000 indicated they were graduate students and 64,000 indicated they were undergraduate students, the 2011 national online learners' priorities report (Noel-Levitz, 2011) revealed the following: over three years between 2008 and 2011, the majority of the online learners are females (female: $67 \%$, male: $33 \%$ ), enrolled at an undergraduate program (undergraduate: $66 \%$, graduate: $34 \%$, other: $4 \%$ ), range in age from 25 to 44 years old (25-34 years: 30\%, 35-44 years: $28 \%$, 45 54 years: $20 \%, 24$ and under: $15 \%, 55$ and over: $7 \%$ ), and are employed full-time while working on their degrees (full-time: 61\%, other: 39\%) (Noel-Levitz, 2011). Acknowledging the current online learners' demographic profile, this study examined whether the profiles (gender, degree program, and age) influence how these learners balance communication privacy concerns and the desire to disclose information. Specifically, the following two research questions (RQ) are sought after:

- RQ 1. Are certain demographics more willing to disclose to particular groups in relation to others (i.e. the instructor, teacher's assistant(s) $(\mathrm{TA}(\mathrm{s}))$, classmates, group members, close friends)?

- RQ 2. Are certain demographics more willing to disclose particular types of information (e.g., personal, appearance, work-related, educational-background, course-specific, and contact information)?

\section{Method}

\section{Recruitment}

Using Wilson's (1997) text titled, "Distance Degrees" as a guide, the first step in the recruitment process was to identify education programs that offer online courses. After higher education programs were identified, course instructors were identified and contacted through email. An email invitation was distributed to 6,500 identified email addresses, asking for the instructors' support by forwarding the research invitation message to their students. Undergraduate and graduate students were invited to participate; the only requirement was experience with online courses at the time of recruitment.

\section{Participants}

The population size was unknown because it was not clear how many students received the invitations from their instructors; however, because sample size does not change much for populations larger than 20,000 , a sample size of 377 was set to obtain a $95 \%$ confidence level with $5 \%$ margin of error and $50 \%$ response distribution. When the target sample of completed surveys was collected through Zoomerang, a commercial online survey service, the survey link was deactivated. Participants' demographic information is illustrated in Table 1. 
Table 1: Demographic characteristics of participants

\begin{tabular}{|l|l|c|}
\hline \multicolumn{1}{|c|}{ Category } & \multicolumn{1}{|c|}{ Ranges } & Percent \\
\hline Age & $18-25$ & 35.54 \\
\hline & $26-39$ & 38.99 \\
\hline Gender & Over 40 & 25.46 \\
\hline & Male & 21.75 \\
\hline Educational enrollment & Female & 78.25 \\
\hline & Undergraduate & 30.77 \\
\hline Employment status & Graduate & 69.23 \\
\hline & Not employed & 15.92 \\
\hline & Employed part-time & 31.30 \\
\hline & Employed full-time & 50.66 \\
\hline & Self-employed & 2.12 \\
\hline
\end{tabular}

\section{Instrument}

Literature was reviewed on the topic of social awareness, and a pool of survey questions was generated. The questionnaire was reviewed by a panel of faculty in the field of education, in order to establish face validity. The newly-created questionnaire was then pilot tested to a group of 56 online course taking students at a medium size private university in a Northeastern State.

The survey contained two categories of questions. The first category of questions (a total of 21 questions) collected participants' demographic information, e.g., "What is your gender?", and online learning experiences, e.g., "How many online courses are you taking currently?" The second category of questions (a total of 52 questions) collected the data representing participants' social awareness within online classroom settings, e.g., "In an online course during the first few weeks of the semester/quarter, what kind of personal information is most effective with helping you to get acquainted with people?"; and group-specific confidentiality questions within online classroom settings, e.g., "In an online course, of the following people, to whom are you willing to share your major information? - teacher, teaching assistant or mentor, classmates, coursework group members, personally close friends in class, and none of the above."

Social information that students gather in online settings to become acquainted with others (Useful $=1$; Not Useful $=0$ ) and willingness to disclose relationship-based online information (Willing $=1$; Non-willing $=0$ ) were scored using a dichotomous procedure. To ensure the internal consistency of the dichotomous survey scores of the sample, a series of Kuder-Richardson Formula 20 (KR-20) tests were computed. Calculated KR-20 alpha coefficients of reliability were $0.82,0.77$ and 0.99 , respectively. User responses for each audience group and information category were computed $(0=$ Not share with any one; $5=$ Share with all audience groups) for analysis. The measured reliabilities using Cronbach's alpha were .873 and .906 , respectively.

\section{Results}

Due to the non-normality of the data, unequal variances between groups, and unequal sample sizes, a Kruskal-Wallis test was conducted to evaluate differences in participants' willingness to share information with various audience groups. Differences in age group were also analyzed using Kruskal-Wallis tests. For tests with only two groups, such as gender and degree programs, a Mann-Whitney $U$ test was conducted to again account for the non-normality of the data, unequal variables between groups, and unequal sample sizes. A large number of group comparisons 
were generated; to counteract the problem of multiple comparisons, the Bonferroni correction method was used and an individual alpha level of 0.001 was set to control Type 1 error.

Among the studied demographic categories, only the degree program category demonstrated group differences in self-disclosure with varied audience groups. Results showed that graduate students (over 25 years: $81.6 \%$; $18-25$ years: $18.4 \%$ ) were consistently more willing than undergraduate students (18-25 years: $74.1 \%$; over 25 years: $25.9 \%)$ to share more information with each audience group; significant results at the .001 level appeared within the teacher $(z=-4.58, p$ $<.001)$, the classmates, $(\mathrm{z}=-4.97, \mathrm{p}<.001)$, the group-members $(\mathrm{z}=-3.23, \mathrm{p}<.001)$, and the TA $(\mathrm{z}=-4.19, \mathrm{p}<.001)$. In addition, undergraduate students were more likely than graduate students to withhold information from all groups $\left(\mathrm{c}^{2}(2, \mathrm{~N}=310)=18.77, \mathrm{p}<.001\right)$. Participants' willingness to disclose information to the friends did not differ significantly at the .001 as it relates to degree programs. Table 2 outlines the mean and standard deviations for each group.

Table 2: Mean and standard deviation values for each group

\begin{tabular}{|l|c|c|c|c|}
\hline \multirow{2}{*}{ Category } & \multicolumn{2}{|c|}{ Undergraduate } & M & SD \\
\cline { 2 - 5 } & M & SD & 26.34 & 4.82 \\
\hline Teacher & 22.02 & 7.07 & 20.82 & 5.64 \\
\hline Classmates & 16.42 & 6.76 & 21.27 & 6.71 \\
\hline Group-members & 16.53 & 7.76 & 22.18 & 7.65 \\
\hline Friends & 21.07 & 7.58 & 23.25 & 6.27 \\
\hline TA & 18.31 & 8.32 & 2.99 & 2.03 \\
\hline $\begin{array}{l}\text { No Group } \\
\text { Average of All } \\
\text { Means }\end{array}$ & 5.00 & 3.65 & $\mathbf{1 9 . 4 8}$ & \\
\hline
\end{tabular}

Degree program, again, demonstrated group differences in self-disclosure of types of information. Results showed that graduate students were consistently more willing than undergraduate students to share all categories of information; a significant difference at the .001 level appeared in the work category $(\mathrm{z}=-4.46, \mathrm{p}<.001)$ and contact information category $(\mathrm{z}=-4.52, \mathrm{p}<.001)$. Table 3 outlines the mean and standard deviation values that represent specific categories of information.

\section{Table 3: Mean and standard deviation values for specific categories of information}

\begin{tabular}{|l|c|c|c|c|}
\hline \multirow{2}{*}{ Category } & \multicolumn{2}{|c|}{ Undergraduate } & M & SD \\
\cline { 2 - 5 } & $\mathbf{M}$ & SD & 21.21 & 5.46 \\
\hline $\begin{array}{l}\text { Personal Informa- } \\
\text { tion }\end{array}$ & 18.62 & 6.54 & 11.41 & 5.70 \\
\hline $\begin{array}{l}\text { Appearance Infor- } \\
\text { mation }\end{array}$ & 9.07 & 6.04 & 22.05 & 4.82 \\
\hline $\begin{array}{l}\text { Work Information } \\
\begin{array}{l}\text { Education Informa- } \\
\text { tion }\end{array}\end{array} \quad 16.80$ & 6.97 & 20.99 & 3.94 \\
\hline \begin{tabular}{l} 
Course Information \\
\hline Contact Information
\end{tabular} & 18.75 & 4.69 & 22.78 & 9.48 \\
\hline $\begin{array}{l}\text { Average of All } \\
\text { Means }\end{array}$ & 10.65 & 10.52 & 15.41 & 5.97 \\
\hline
\end{tabular}




\section{Discussion}

The results of the study provide important insights into how graduate students and undergraduate students differ in their management preferences of privacy settings in online learning environments; however, no significant differences were found between gender and age.

While previous research suggests that gender can determine the extent to which a student will disclose private information (Barak \& Gluck-Ofri, 2007; Petronio, 2002), the current study, as highlighted by Fogel and Nehmad (2009), found that gender was not a discriminating factor for self-disclosure preference. Research in the area of psychology has suggested that females perceive more positive benefits related to information disclosure when compared to males (Petronio $\&$ Martin, 1986), but recent literature in online privacy preferences does not necessarily support this implication (Acquisti \& Gross, 2006). The current study found that male and female students demonstrate relatively similar information disclosure preferences, suggesting that both genders balance privacy concerns with information disclosure preferences in a comparable manner. It should be noted, however, that the majority of the study's participants were female $(78.25 \%)$, which may have influenced the results.

Recent literature has also shown that younger students tend to be less concerned with privacy when compared to older students (Tufekci, 2008) and has proven that the amount of selfdisclosure is diminished as age increases (Kisilevich, Ang, \& Last, 2011; Nosko, Wood, \& Molema, 2009). This study's findings, however, showed no preference difference between the three age groups (18-25; 26-39; 40 and over). Research focusing on age and information disclosure habits often show that younger participants are more willing than older participants to place less value on personal information, such as political views and sexual orientation (Stutzman, 2006); yet, the current study surveyed students within similar educational settings, and focused on less personal, identifying information, such as personal photos.

The current study's findings suggest a significant relationship between degree type and information disclosure preferences: Graduates students were more willing than undergraduate students to share specific categories of information (personal, appearance, work, education, course, and contact information), particularly work and contact information. In line with CPM, undergraduate students, who possess less relevant and incomplete work and contact information profiles, may feel these categories do not fall in line with the rules and boundaries for acceptable informationsharing habits (Petronio, 2002). In light of findings highlighted by Gross and Aquisti (2005), participants' perceptions of the benefits associated with information disclosure determine the online privacy behavior. CPM posits that students weigh the risks of disclosing particular information in an online environment such that the lower the perceived risk the more likely they will disclose information. These findings suggest that graduate students are more willing than undergraduate students to favor personal connections over privacy needs.

When looking at the different groups of users (teachers, classmates, group members, friends, and TAs), graduate students were also more willing than undergraduate students to share information with teachers, classmates, group members, and TAs. While this study did not examine motivation factors in relation to privacy concerns, the literature indicates that graduate students exhibit stronger intrinsic motivation than undergraduate students (Rovai, Ponton, Wighting, \& Baker, 2007); as self-motivated learners have a desire to make interpersonal connections and assimilate their personality according to their surroundings (Gagne \& Deci, 2005), graduate students are likely to disclose more information to a diverse set of users in order to reach a higher level of social learning. These findings again show a trend for graduate students to relinquish a certain level of privacy in return for reaching a higher level of social learning.

In support of CPM, these two major findings reveal that graduate students, who are often recognized as more self-motivated learners, prioritized their desire to make personal connections over 
their need to maintain privacy boundaries. This behavior shows that students, including both undergraduate and graduate students, consider privacy when presenting themselves in online environments, but actively set rules and boundaries according to their desire to actively participate in a social learning environment. As social learning plays an important role in the success of an online learning environment (Huang, 2002), these findings suggest that instructors and practitioners need to be cautious of privacy boundaries when attempting to conduct social learning activities. By employing technology such as communication privacy and disclosure management systems (see Heo, 2011), instructors may provide environments where online students actively configure privacy settings based on information type and group (teachers, classmates, etc.), giving students more control over individual privacy boundaries.

\section{Limitations}

While the results provide insights for online learners' social behavior and information disclosure preferences, a few limitations need to be noted. First, the study was based upon the self-reported views and preferences from an online questionnaire without observation of actual behaviors of online learners. Since there often exists discrepancy between stated preferences and actual behavior of privacy among online users (giving away more information about themselves than their stated preferences) (Berendt, Günther, \& Spiekermann, 2005), online learners' actual information disclosing behavior could differ from what was reported in this study. Future in-depth studies using methods of observation is recommended to further extend our understanding of online learners' information sharing preferences and actual practices.

Second, the analysis was made based upon the demographic information provided by the participants. Personal motivation and learning styles, which were outside the scope of the current study, may provide another point of view regarding students' willingness and unwillingness to disclose information. Examining learners' personal information may supplement the findings of the current study and possibly reveal learning styles that could explain individual motivation for certain social behaviors.

Finally, the various groups, including teachers, classmates, group members, friends, and TAs, were classified according to their academic and/or professional position. This study's findings indicate that graduate students were more willing to disclose information to all of the groups with the exception of the friends group. The results may provide a different perspective if research were to focus on whether the students understand the roles of these particular groups (teachers, classmates, etc.) and if there is a perceived benefit in the relationship according to the student. Perhaps examining the learners' perceptions of their already established relationships could provide additional insight into information disclosure behavior.

\section{Conclusions}

Using CPM as a theoretical framework, the study originally assessed age, gender, and the degree program as indicators of information-sharing preferences. Results revealed that among the categories of demographics examined, degree program is the only predictor of information disclosure preferences. The results showed that graduate students were significantly more likely than undergraduate students to share information with many different groups, including teachers, classmates, group-members, and the TA group. In addition, graduate students were more likely than undergraduate students to share all categories of information, especially work-related information and contact information.

While this study focused on privacy preferences, future studies may benefit from studying motivations that support information disclosure habits. In support of CPM, we speculate that different levels of learners have various motivations for disclosing information to certain groups of people. 
For example, graduate students may perceive developing relationships with their professors, fellow classmates and TAs as beneficial. Therefore, future research can examine online learners' perceived relationship with different groups of users to confirm their motivations for revealing otherwise private information. Future research could also compare the amount of information the learner actually holds with the amount of information that is disclosed. These findings could reveal whether the learner is withholding information that actually exists or if they are simply not disclosing because there is minimal information to reveal.

Finally, future research may link information disclosure habits with students' perceived social presence in online learning environments. The Social Presence Theory (SPT), which suggests that communication is directly associated with the level at which people feel socially aware of each other (Richardson \& Swan, 2003), may help future researchers further explore the importance of students' information disclosure habits. Students' perceived level of learning in online learning environments has been shown to directly correlate with their perceived level of social interaction (Richardson \& Swan, 2003). Such results indicate that students who are more actively engaged in online learning environments, and who are able to make connections with other students, tend to succeed in online courses (Richardson \& Swan, 2003). Future research may further explain online learners' willingness or unwillingness to disclose information by identifying particular perceptions of learners and whether these perceptions are connected to learners' motivational needs and online social presence.

\section{References}

Acquisti, A., \& Gross, R. (2006). Imagined communities: Awareness information sharing, and privacy on the Facebook. In P. Golle \& G. Danezis (Eds), Proceedings of 6th Workshop on Privacy Enhancing Technologies (pp. 36-58). Cambridge, UK: Robinson College. Retrieved from http://privacy.cs.cmu.edu/dataprivacy/projects/facebook/facebook2.pdf

Alexander, B. (2008). Social networking in higher education. In R. N. Katz (Ed.), The tower and the cloud: Higher education in the age of cloud computing (pp. 197-201). Washington, D.C.: EDUCAUSE.

Ally, M. (2004). Foundations of educational theory for online learning. In T. Anderson \& F. Elloumi (Eds), Theory and practice of online learning (pp. 3-31). Canada: Athabasca University.

Anderson, T. (2004). Toward a theory of online learning. In T. Anderson \& F. Elloumi (Eds), Theory and practice of online learning (pp. 33-60). Canada: Athabasca University.

Barak, A., \& Gluck-Ofri, O. (2007). Degree and reciprocity of self-disclosure in online forums. Cyber Psychology \& Behavior, 10, 407-417. doi:10.1089/cpb.2006.9938

Berendt, B., Günther, O., \& Spiekermann, S. (2005). Privacy in e-commerce: Stated preferences vs. actual behavior. Communications of the ACM, 48, 101-106. doi:10.1145/1053291.1053295

Boyd, D. M., \& Ellison, N. B. (2008). Social network sites: Definition, history, and scholarship. Journal of Computer-Mediated Communication, 13(1), 210-230. doi:10.1111/j.1083-6101.2007.00393.x

Cercone, K. (2008). Characteristics of adult learners with implications for online learning design. $A A C E$ Journal, 16, 137-159. Retrieved from http://www.editlib.org/p/24286

Chen, B., \& Bryer, B. (2012). Investigating instructional strategies for using social media in formal and informal learning. The International Review of Research in Open and Distance Learning, 13, 87-104. Retrieved from http://www.irrodl.org/index.php/irrodl/article/view/1027/

Child, J. T., \& Petronio, S. (2011). Unpacking the paradoxes of privacy in CMC relationships: The challenges of blogging and relational communication on the internet. In K. B. Wright \& L. M. Webb (Eds.), Computer-mediated communication in personal relationships (pp. 21-40.) New York: Peter Lang. Retrieved from http://www.heinz.cmu.edu/ acquisti/shb/Petronio.pdf 
Chou, P.-N., \& Chen, W.-F. (2009). Name-display feature for self-disclosure in an instant messenger program: A qualitative study in Taiwan. Informing Science and Information Technology, 6, 113-126. Retrieved from http://iisit.org/Vol6/IISITv6p113-126Chou651.pdf

Cobb, S. C. (2009). Social presence and online learning: A current view from a research perspective. Journal of Interactive Online Learning, 8(3), 241-254. Retrieved from http://www.ncolr.org/jiol/issues/pdf/8.3.4.pdf

Dabbagh, N., \& Kitsantas, A. (2012). Personal learning environments, social media, and self-regulated learning: A natural formula for connecting formal and informal learning. Internet and Higher Education, 15, 3-8. doi:10.1016/j.iheduc.2011.06.002

Darkenwald, G. G., \& Merriam, S. B. (1982). Adult education: Foundations of practice. New York, NY: Harper \& Row.

Dron, J. (2007). Designing the undesignable: Social software and control. Journal of Educational Technology and Society, 10, 60-71. Retrieved from http://www.ifets.info/journals/10 3/5.pdf

Fogel, J., \& Nehmad, E. (2009). Internet social network communities: Risk taking, trust, and privacy concerns. Journal of Computers in Human Behavior, 25, 153-60. doi:10.1016/j.chb.2008.08.006

Forkosh-Baruch, A., \& Hershkovitz, A. (2011). The use of social networks by higher-education institutes in Israel. Proceedings of the Chais conference on instructional technologies research 2011: Learning in the digital era, pp. 14-20. Retrieved from http://shoham.openu.ac.il/chais2011/download/Forkosh_Hershkovitz.pdf

Gagne, M., \& Deci, E. L. (2005). Self-determination theory and work motivation. Journal of Organizational Behavior, 25, 331-362. doi:10.1002/job.322

Gerstein, S. (1984). Intimacy and privacy. In F. D. Schoeman (Ed.), Philosophical dimensions of privacy: An anthology. Cambridge,UK: Cambridge University Press.

Gross, R. \& Acquisti, A. (2005). Information revelation and privacy in online social networks (the Facebook case). Proceedings from the 2005 ACM Workshop on Privacy in the Electronic Society, New York, $N Y, 71-80$. doi:10.1145/1102199.1102214

Heo, M. (2011). Communication privacy disclosure management: An empirical study of socialization support in a pseudo-online class. Journal of Interactive Online Learning, 10, 76-95.

Huang, H. M. (2002). Toward constructivism for adult learners in online learning environments. British Journal of Educational Technology, 33, 27-37. doi:10.1111/1467-8535.00236

Junco, R. (2011). The relationship between frequency of Facebook use, participation in Facebook activities, and student engagement. Computers \& Education, 58, 162-171. doi:10.1016/j.compedu.2011.08.004

Kiriakidis, P. (2008). Online learner satisfaction: Learner-instructor discourse. College Teaching Methods \& Styles Journal, 4, 11-18. Retrieved from http://etec.hawaii.edu/proceedings/2007/kiriakidis.pdf

Kisilevich, S., Ang, C. S., \& Last, M. (2011). Large-scale analysis of self-disclosure patterns among online social networks users: A Russian context. Knowledge and Information Systems, 32(3), 609-628. doi:10.1007/s10115-011-0443-z

Kreijns, K., Kirschner, P. A., \& Jochems, W. (2003). Identifying the pitfalls for social interaction in computer-supported collaborative learning environments: A review of research. Computers in Human Behavior, 19, 335-353. doi:10.1016/S0747-5632(02)00057-2

Leskovec, L., Huttenlocher, D., \& Kleinberg, J. (2010). Signed networks in social media. Proceedings of the $28^{\text {th }}$ ACM Conference on Human Factors in Computing Systems (pp. 1361-1370). Atlanta, GA: ACM. doi:10.1145/1753326.1753532

Livingstone, S., \& Brake, D. (2010). On the rapid rise of social networking sites: New findings and policy implications. Children and Society, 24, 75-83. doi:10.1111/j.1099-0860.2009.00243.x 
Ma, W. W. K., \& Yuen, A. H. K. (2010). Understanding online knowledge sharing: An interpersonal relationship perspective. Computers \& Education, 56, 210-219. doi:10.1016/j.compedu.2010.08.004

Madge, C., Meek, J., Wellens, J., \& Hooley, T. (2009). Facebook, social integration and informal learning at university: 'It is more for socialising and talking to friends about work than for actually doing work'. Learning, Media and Technology, 34(2), 141-155.

Metzger, M. J. (2007). Communication privacy management in electronic commerce. Journal of ComputerMediated Communication, 12, 335-61. doi:10.1111/j.1083-6101.2007.00328.x

Noel-Levitz (2011). Priorities survey for online learners. Retrieved from https://www.noellevitz.com/upload/Papers and Research/2011/PSOL_report\%202011.pdf

Nosko, A., Wood, E., \& Molema, S. (2009). All about me: Disclosure in online social networking profiles: The case of FACEBOOK. Computers in Human Behavior, 26, 406-418. doi:10.1016/j.chb.2009.11.012

Palen, L., \& Dourish, P. (2003). Unpacking "privacy" for a networked world. CHI Letters, 5, 129-136. doi: $10.1145 / 642611.642635$

Petronio, S. (2002). Boundaries of privacy: Dialectics of disclosure. New York, NY: State University of New York Press.

Petronio, S., \& Martin, J. N. (1986). Ramifications of revealing private information: A gender gap. Journal of Clinical Psychology, 42, 499-506. doi:10.1002/1097-4679(198605)42:33.0.CO;2-I

Polhemus, L., Shih, L.-F., \& Swan, K. (2001). Virtual interactivity: The representation of social presence in an online discussion. Paper presented at the Annual Meeting of the American Educational Research Association, Seattle, WA.

Richardson, J. C., \& Swan, K. (2003). Examining social presence in online courses in relation to students' perceived learning and satisfaction. Journal of Asynchronous Learning Networks, 7, 68-88. Retrieved from https://www.ideals.illinois.edu/bitstream/handle/2142/18713/RichardsonSwan\%20JALN7(1).pdf?sequ $\underline{\text { ence }=2}$

Roblyer, M. D., McDaniel, M., Webb, M., Herman, J., \& Witty, J. V. (2010). Findings on Facebook in higher education: A comparison of college faculty and student uses and perceptions of social networking sites. The Internet and Higher Education, 13, 134-140. doi:10.1016/j.iheduc.2010.03.002

Rovai, A. P., Ponton, M. K., Wighting, M. J., \& Baker, J. D. (2007). A comparative analysis of student motivation in traditional classroom and e-learning courses. International Journal on E-Learning, 6 , 413-432. Retrieved from http://www.eric.ed.gov/ERICWebPortal/search/detailmini.jsp?_nfpb=true\&_\&ERICExtSearch_Search Value $0=$ EJ763593\&ERICExtSearch_SearchType $0=$ no\&accno=EJ763593

Simonson, M., Smaldino, S., Albright, M., \& Zvacek, S. (2000). Teaching and learning at a distance: Foundations of distance education. Upper Saddle River, NJ: Merrill

Smith, S., Salaway, G., \& Caruso, J. (2009). The ECAR study of undergraduate students and information technology, 2009 (Volume 6). Retrieved from EDUCAUSE Center for Applied Research website: https://net.educause.edu/ir/library/pdf/ers0906/rs/ERS0906w.pdf

Song, L., Singleton, E. S., Hill, J. R., \& Koh, M. H. (2004). Improving online learning: Student perceptions of useful and challenging characteristics. The Internet and Higher Education, 7(1), 59-70. doi:10.1016/j.iheduc.2003.11.003

Strater, K., \& Lipford, H. R. (2008). Strategies and struggles with privacy in an online social networking community. In Proceedings of the 22nd British HCI Group Annual Conference on People and Computers: Culture, Creativity, Interaction-Volume 1 (pp. 111-119). Chicago: British Computer Society.

Stutzman, F. (2006). An evaluation of identity-sharing behavior in social network communities. iDMAa Journal, 3. Retrieved from http://www.units.muohio.edu/codeconference/papers/papers/stutzman_track5.pdf 
Stutzman, F., \& Kramer-Duffield, J. (2010, April). Friends only: Examining a privacy-enhancing behavior in Facebook. In Proceedings of the 28th international conference on Human factors in computing systems (pp. 1553-1562). ACM. doi:10.1145/1753326.1753559

Sung, E., \& Mayer, R. E. (2012). Five facets of social presence in online distance education. Computers in Human Behavior, 28(5), 1738-1747. doi:10.1016/j.chb.2012.04.014

Swan, K. (2002). Building learning communities in online courses: The importance of interaction. Education, Communication \& Information, 2,2 3-49. doi:10.1080/1463631022000005016

Tufekci, Z. (2008). Can you see me now? Audience and disclosure regulation in online social network sites. Bulletin of Science Technology Society, 28, 20-36. doi:10.1177/0270467607311484

Walther, J. B. (1996). Computer-mediated communication impersonal, interpersonal, and hyperpersonal interaction. Communication Research, 23(1), 3-43. doi:10.1177/009365096023001001

Walther, J. B., \& Parks, M. R. (2002). Cues filtered out, cues filtered in. In M. L. Knapp \& J. A. Daly (Eds), Handbook of interpersonal communication (pp. 529-563). Thousand Oaks, CA: Sage.

Wilson, M. (1997). Distance degrees. Kearney, NE: Morris Publishing.

Ziegler, M., Paulus, T., \& Woodside, M. (2006). Creating a climate of engagement in a blended learning environment. Journal of Interactive Learning Research, 17, 295-318. Retrieved from http://www.editlib.org/p/6286

\section{Biographies}

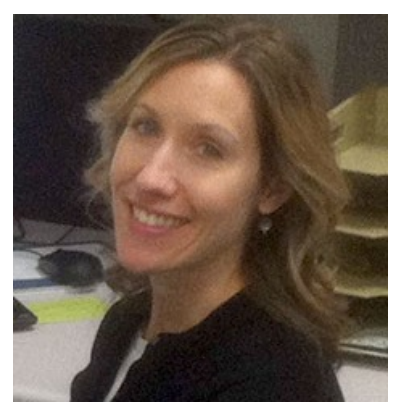

Anne T. Doring is a doctoral student enrolled in the Instructional Technology program at Duquesne University. Her research concentrations include knowledge creation and social presence within Learning Management Systems as well as teacher leadership and development. She may be contacted at doringa@duq.edu.

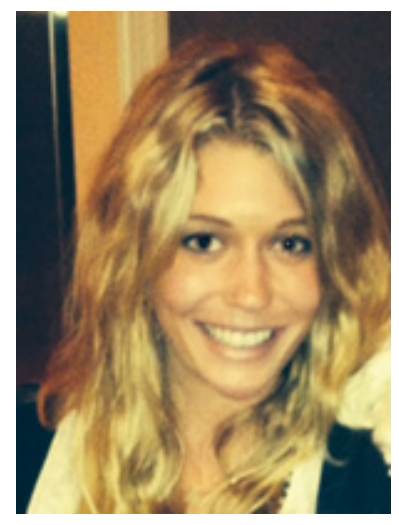

Ashley Hodge is a doctoral candidate in the Instructional Technology program at Duquesne University. Her main research concentrations are teaching and learning with online social network systems and professional learning communities in education. She may be contacted at hodgea@duq.edu . 


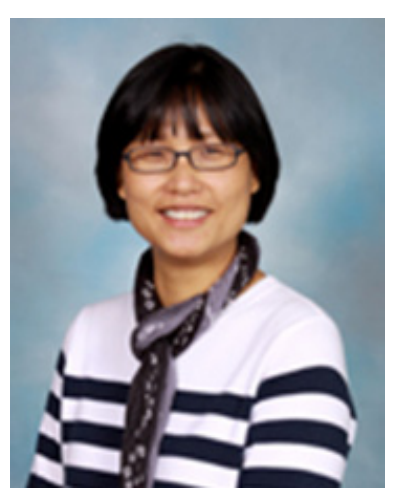

Dr. Heo earned her doctoral degree in Information Science from the University of Pittsburgh. Her area of expertise resides in information technology and instructional technology. Her research interests include information visualization, specifically, visualization of personalized social information in online education, and user sustainability in Web portals. She has taught information technology courses (e.g., Internet technology and interface design) and instructional technology courses (e.g., digital imagery and instructional applications of technology). She may be contacted at heom@duq.edu. 